\title{
The Determinants of Housing Tenure Choice: Evidence from Micro Data
}

Francis Tandoh

\author{
PhD Candidate, School of Accounting, Economics and Finance, College of Law and Management, \\ University of KwaZulu-Natal, Westville Campus- Durban, South Africa \\ bigtandoh@yahoo.co.uk
}

\section{Davi Datt Tewari}

Professor, School of Accounting, Economics and Finance, College of Law and Management, University of KwaZulu-Natal, Westville Campus- Durban, South Africa tewari@ukzn.ac.za

\author{
Doi:10.5901/mjss.2013.v4n13p597
}

\begin{abstract}
Ghana has three dominant modes of housing tenure: owner occupancy, renting and rent free. Rent free has been a substantial tenure mode in Ghana over the years. It was the major type of tenure in the country before 1998 when it became the next major type of tenure after owning (GSS, 2005). This study aims at estimating the determinants of the housing tenure decisions in Ghana. it employed the multinomial logit model to achieve this objective. It was found that a household's decision to rent is positively influenced by location in the forest and coastal ecological zones, urban location, a household head with basic education and the income of the household head. Location in the forest ecological zone, urban location, household heads with bachelor's degrees and employed household heads are the main positive determinants of the decision to stay rent free. Rent free, as a tenure choice is substantial and serves young graduates; the state should therefore make deliberate efforts to sustain and maintain the extended family system, since it is the major provider of rent free housing units in Ghana
\end{abstract}

\section{Introduction}

Housing is a basic necessity of life. In every country housing is one of the key determinants of quality of life of the citizens. As a result, governments all over the world have been trying to provide housing for their populace (Habitat, 2005). Despite the benefits of housing, the benefit to the individual depends on the tenure modes it occupies. The housing literature identifies renting and owner occupation as the main tenure modes (Henderson and loannides, 1983).

Owner occupation is better than renting. Haurin et al. (2002) found that home owning led to a 13 to 23 percent higher quality home environment, greater cognitive ability and fewer child behaviour problems. The study concluded that children who lived in owner-occupied homes had 9 percent higher mathematics score and 7 percent higher reading achievement than those who lived in other housing tenure modes. Such children had about 3 percent lower behavioural problems. Owner occupation helps to provide local amenities and leads to improvement in the neighbourhood (Dipasquale and Glaeser, 1999). The superiority of home owning to renting made US authorities subsidized owner occupied housing investment (Engelhardt et al. 2010). Home owning has its shortcomings, owning involves high mobility cost as a result owners are less likely to move. This may lead to structural unemployment leading to lower potential growth (Raya and Garcia, 2012). The lower probability of mobility also affects owners in a situation where the quality of the neighbourhood deteriorates. Renter households may relocate to avoid the negative consequence of this deterioration.

Ghana has three dominant modes of housing tenure: owner occupancy, renting and rent free. Although perching is a further mode of tenure, it is not popular with the majority of the population. There are substantial variations in the tenure structure in the various regions in the country as well as between the various localities (rural and urban). In the urban areas, ownership averages 41.1 percent compared with an ownership rate of 71 percent in the rural areas. Renting is uncommon in the rural areas, representing only 9.9 percent, but substantial in the urban areas, measuring 35.8 percent. Trends in the choice of tenure show that home ownership has increased over the years. Renting is also increasing, although the rate of increase is very slow. While the percentage of rent free tenure is falling, it remains substantial, demonstrating that the housing market is not fully developed; this distorts the efficiency of the market. Table 1 shows that 
ownership is increasing over time in the urban areas, although the rate of increase is lower than in the rural areas.

Table 1 further shows that rent free is a major tenure choice in Ghana; Rent free has been a substantial tenure mode in Ghana over the years. It was the major type of tenure in the country before 1998 when it became the next major type of tenure after owning (GSS, 2005). This type of tenure comes about as a result of the extended family system in Ghana. The result of the GLSS-5 showed that extended family accounted for 82 percent of the rent free occupants. The rest of rent free was due to 'caretaker' system. Due to inadequate finance, housing was done incrementally. That is house owners built their houses over a long period of time, stopping when resources are limited and building when resources became available. This basic housing delivery mechanism explains the caretaker "rent-free" tenure. The fact that housing is delivered over a long period of time allows "free riders" to occupy homes for "rent free" for a long period of time, so long as the owner continues to build incrementally. However, the concept of "rent-free" is highly contested, many instances, what is considered to be "rent- free" is not really the case, as there are non-cash payments for the use of such accommodation. Sometimes, people have to take care of the utility bills and other soft costs of the house as their contributions. In other cases, this comes in several forms depending on the particular context and circumstances. Sometimes, it may come in the form of an "agreement" (may not be documented) in the form of the occupier keeping the building in a general state of repair (weeding around the house, cleaning, alerting owner of any structural defects among other things) as well as ensuring the security of the building as well as the building materials that are normally stored for future use (e.g. floor and wall tiles, ceiling elements, plumbing and electrical materials including pipes). These arrangements do not mostly happen in the extended family.

Table 1: Trend in the Tenure Modes in Ghana

\begin{tabular}{|c|c|c|c|c|c|c|c|c|c|c|c|c|}
\hline \multirow[b]{2}{*}{ Tenure } & \multicolumn{4}{|c|}{ Rural } & \multicolumn{4}{|c|}{ Urban } & \multicolumn{4}{|c|}{ National } \\
\hline & 1993 & 1998 & 2006 & 2010 & 1993 & 1996 & 2006 & 2010 & 1993 & 1998 & 2006 & 2010 \\
\hline Owning & 47.8 & 52 & 58.7 & 62.1 & 17 & 24.3 & 26.1 & 28.7 & 37 & 41.9 & 44.6 & 47.2 \\
\hline Renting & 4.8 & 10.5 & 9.1 & 11.2 & 39.4 & 36.1 & 40.9 & 50.3 & 19.6 & 19.9 & 22.8 & 31.1 \\
\hline Rent free & 42.8 & 37.2 & 32 & 15.2 & 42.4 & 38.8 & 31.7 & 25.1 & 42.7 & 37.8 & 31.9 & 20.8 \\
\hline perching & 0.4 & 0.2 & 0.3 & 0.4 & 1.2 & 0.8 & 1.3 & 1.6 & 0.7 & 0.5 & 0.7 & 0.8 \\
\hline
\end{tabular}

Note: the GSS (1993) was used for the 1993 figures, GSS(1998) was used for the 1998 figures and GSS(2008) for 2006 figures while GSS(2010) was used for the 2010 figures.

\section{Source: Based on data from GSS (1993, 1998, 2008 and 2010)}

The housing literature of Ghana is silent on the determinants of housing tenure choice. Therefore an investigation into this is necessary for making a good housing policy in the country. The aim of this study is to investigate the determinants of housing tenure choice in Ghana in the wake of acute housing shortage in the country. Although literature on tenure choice abound, much dwells on developed economies. The few studies on developing countries use owning and renting as the main tenure status for the analysis. This study considers a new tenure mode rent free which is peculiar and has been a major tenure status in Ghana over a long time but no attention has been given to it in tenure analysis. An insight into the rent free tenure is essential as it constitutes one-third (GSS, 2008) of the housing market in Ghana. Tenure choice analysis is vital to understand the housing situation and portfolio choice of a country. The results of this study can be used to explain the saving behaviour of the households in Ghana especially in the wake of the increasing incomes per capita.

The discussion and analysis are organized under 5 sections. The section 2 looks at the review of related literature followed by a conceptual framework in section 3 . Analysis of results is given in section 4 . Final conclusions and policy implications are discussed in section 5

\section{Literature}

Rosen (1979) and Jones's (1995) theories dominate the literature on housing tenure. The theory of housing tenure choice outlined by Rosen (1979) is premised on the utility maximisation framework. An individual household is assumed to maximise its utility by selecting the choice of tenure that maximises utility subject to budget constraints. The choice of tenure is mutually exclusive; although all tenure modes provide housing services they are different commodities due to their different characteristics (Rosen, 1979). A housing unit of similar characteristics but in different tenure modes is not expected to be preferred to the same extent by different kinds of households. The utility of the household was therefore 
formulated differently for different households according to tenure. A household $j$ that chooses to own would have a utility given as:

$$
v_{j}^{o}=V\left(p_{j}^{o}, p_{x j}, y_{j}\right)
$$

where $V($.$) represents the indirect utility of the household; p_{j}^{o}$ is the user cost of owning; $p_{x j}$ is the price of all other goods; and ${ }^{y_{j}}$ is the income of household. Similarly if the household chooses to rent then the utility function is given as:

$$
V_{j}^{R}=V\left(p_{j}^{R}, p_{x j}, y_{j}\right)
$$

Where $V($.$) represents the in the indirect utility of the household; p_{j}^{R}$ is the user cost of owning; $p_{x j}$ is the price of all other goods; and $y_{j}$ is the income of household. From the utility functions, the households would choose to own if $V_{O}-V_{R}>0$ and rent if $V_{O}-V_{R}<0$. The empirical formulation of this decision is based on the discrete choice approach. Jones (1995) outlined seven shortcomings of Rosen's (1979) model:

That (1) it was difficult to reconcile a positive and elastic ( $\mathrm{Po} / \mathrm{Pr}$ ) hypothesis for ownership; (2) there was no evidence to show that risk neutral, high tax bracket households would own rather than rent in the long run; (3) empirical Previous studies ambiguous impact of inflation on $\mathrm{P}_{0} / \operatorname{Pr}$ as positive rather than negative, as posited by Rosen; (4) empirical studies invalidate tax sorting models; (5) tax-based models were deficient in explaining the difference between owner occupancy in multifamily units and single family units; (6) younger households are averse to holding risky assets such as housing relative to older households; and (7) the presence of liquidity constraints invalidates the assumption of user cost models.

Jones (1979) therefore suggested that owner and rental housing units were distinct goods and weak substitutes; therefore, preferences were determined by attributes (Z) not user cost $\mathrm{Po} / \mathrm{Pr}$ It was argued that permanent households enjoy using some housing services as owners rather than renters. Younger households are risk averse and hence enjoy higher utility from renting rather than owning. They would only own when the difference in utility is zero or when they had accumulated sufficient financial assets as a hedge against house price uncertainty, expressed as the ratio of riskless assets to the value of housing units. A latent binary index showing the difference in utility was stated as:

$$
I=(W, P, Z)
$$

Where $W$ is the liquefiable wealth; $P$ is the stock price of the value of a unit of housing; $Z$ is the household attributes that represent permanent and mobility characteristics. This model placed importance on assets price of housing and liquefiable wealth rather than permanent income and relative price of owning and renting $(\mathrm{Po} / \mathrm{Pr})$. The empirical estimations also used the discrete choice approach. The rejection of the user cost was based on the presumption that ownership and renting are not substitutes. Although this is a contentious issue in tenure literature, it has not affected specification issues in empirical studies (O'Sullivan, 2003).

Arnott (1987) observed that the above mentioned studies provide an economic perspective based on the rational consumer maximising utility, subject to the budget constraint. The main determinants of tenure decisions are therefore income, value to rent ratio and the wealth of the household.

Contrasting views on housing tenure choice are proposed by scholars in other fields such as geography, sociology and demography. They argue that the tenure decision represents a myriad of interlinked characteristics of households and examine variations in the housing market other than the simple investment motives and wealth motives ascribed by the economic perspective (Clark and Dieleman, 1996). Over the past two decades, empirical analysis of tenure has witnessed a merging of these perspectives.

The empirical literature on determinants of tenure in developing countries is sparse compared with that on developed countries. Furthermore, the available literature on developing countries used conventional ownership and rental to analyse tenure choice (Arimah, 1997: Van Lindert and Van Westen, 1991). Morais and Cruz (2002) argued that, the analysis of tenure choice in developing countries should extend beyond the renting versus owning dichotomy. The housing market includes informal tenure like squatting; room renting; bed renting; and sharing with relatives, as well as formal owning and renting. Edwards (1990) maintained that tenure choice alternatives for lower income earners were limited because available tenure was positively related to income. However, when people were grouped according to income, the result was inconclusive. People with similar income chose different tenure arrangements, which means that tenure choice was income inconclusive. Van Lindert and Van Westen (1991) found that some financially unconstrained households in Bamako, Mali, chose renting over owning while in La Paz, Bolivia many of the residents of the 
"Conventillo" chose to remain in this rental residence in the town centre rather than becoming owners on the outskirts of the city. They concluded that the "choice" and "constraint" debate in tenure literature applied to people in the same social categories who fell into the same income bracket.

Daniere (1992) argued that tenure choice in Manila and Cairo extended beyond owning and renting to include squatting. Education, family size, mobility and income were found to be the main determinants of tenure choice. Arimah (1997) stated that the main variables that affected tenure choice in Ibadan were the number of children, gender of the household head, investment motives and access to land.

Koizumi and McCann (2006) modelled tenure choice by adding plot purchase with the intention to build in the future, to traditional renting and owning. They found that the young (below the age of 45 years) had lower rates of home ownership than the old (above 45 years). The number of dependants had a positive relationship with owning. They concluded that the usual dichotomous rent or own used for tenure analysis in developed countries was inadequate for analysing tenure choice in developing countries. Therefore, empirical studies on tenure in developing countries should include other, informal alternatives. Morais and Cruz (2007) analysed the determinants of housing tenure in Brazil by classifying settlements in the country into formal and informal. The study found that race, gender, age and marital status were the main determinants of owning in the formal sector, while single mothers and new migrants were the main determinants of tenure choice in the informal housing sector. These studies of developing countries show that the influence of income on the choice of tenure is not as strong as socio-demographic variables, unlike in developed countries also tax laws are not a determinants of the tenure choice decisions. There is general consensus in the literature on developed countries on the types of tenure, but this is still a contentious issue in the literature on tenure in developing countries.

\section{Empirical Framework}

The estimation of the determinants of the household's choice of tenure for this study borrowed from Goodman (1988; ,2003), who estimated the choice of tenure from the choice probability model and gave the empirical foundation of tenure choice estimation. He stated that the probability of owning (f) rather than renting was a function of value to rent ratio $(\mathrm{Vr})$, relative prices $(\mathrm{Po} / \mathrm{Pr})$, income $(\mathrm{Y})$ and other individual attributes $(A)$, as well as the length of stay $(\mathrm{L})$, i.e.

$$
f=f\left(V r, \frac{p_{o}}{p_{r}}, Y, A, L\right)
$$

The econometric function for this model was of the form

$$
f=a_{Y} Y+a_{P} \frac{p_{O}}{p_{r}}+a_{V} V r+\sum a_{A} A+a_{L} L+\varepsilon_{f}
$$
framework.

This study adapted and expanded equation (5) to include rent free and estimated it in a multinomial logit

The underlining assumption of this model is from the household's utility maximisation framework (Henderson and Ioannides, 1983). The household is assumed to have more than one mutually exclusive tenure alternative to choose from. If the household $i$ chooses the alternative $n$ from possible alternatives, then it can be said that it is the alternative $n$ that maximizes the household's utility. The utility of this individual choosing alternative $n$ can be represented by $U_{\text {in. }}$ This utility $U_{\text {in }}$ can be decomposed into two parts:

1. the observed utility $\left(V_{\text {in }}\right)$ and

2. the unobserved utility $(\varepsilon$ in $)$

The unobserved utility $\left(\varepsilon_{\text {in }}\right)$ is treated as random (Train 2001). The utility function of this individual can therefore be stated as:

$$
U_{i n}=V_{i n}+\varepsilon_{i n} .
$$

If all factors affecting utility are observable then $\varepsilon_{\text {in }}=0$, however in reality all the factors that affect utility cannot be observed. The unobserved factor $\varepsilon_{\text {in }}$ is assumed to be iid extreme value with a density given as:

$$
f\left(\varepsilon_{i n}\right)=e^{-\varepsilon_{i n}} e^{-e^{-\varepsilon i n}}
$$

and a cumulative distribution 


$$
F\left(\varepsilon_{i n}\right)=e^{-e^{-\varepsilon i n}}
$$

Train (2001) argued that the choice of the household could be put into a probability statement based on the person's utility such that:

$$
p_{i n}=\operatorname{prob}\left(u_{i n}>u_{i m}\right)
$$

This means if the household had two alternatives $(n$ and $m$ ) to choose from, choosing alternative $n$ meant that the utility for $n$ was greater than the utility for $m$.

By substituting utility from the equation (6), equation (9) then becomes

$$
p_{\text {in }}=\operatorname{prob}\left(v_{i n}+\varepsilon_{i n}>v_{i m}+\varepsilon_{i m}\right)
$$

This probability can be expressed in a cumulative probability statement such that

$$
p_{\text {in }}=\operatorname{prob}\left(\varepsilon_{i m}-\varepsilon_{\text {in }}<v_{i n}-v_{i m}\right)
$$

This means that the household's choice of alternative $n$ implies that the probability of the error difference is less than the probability of the observed difference (McFadden, 1974). Therefore, the household would choose alternative $n$ in as far as the utility of the error difference does not exceed the utility of the observed difference. However, if the utility of the observed difference exceeds the utility of the unobserved difference, then alternative $m$ would be chosen. The equation (11) can be rewritten as:

$$
p_{i n}=\operatorname{prob}\left(\varepsilon_{i m}<\varepsilon_{i n}+v_{i n}-v_{i m}\right)
$$

This expression is a cumulative distribution function for each $\varepsilon_{i m}$ evaluated at $\varepsilon_{i n}+v_{i n}-v_{i m}$

This is equivalent to equation (6) [Train, 2001]. Because the $\varepsilon$ 's are iid, then the cumulative function overall $n \neq m$ is the product of the cumulative distribution function of the individual given as:

$$
p_{i n} / \varepsilon_{i n}=\prod_{n \neq m} e^{-e\left(e_{i n}+v_{i n}-v_{i m}\right)}
$$

Since $\varepsilon_{\text {in }}$ is unknown the choice probability is therefore the integral of

$$
p_{\text {in }} / \varepsilon_{\text {in }}=\int\left(\prod_{n \neq m} e^{-e\left(e_{i n}+v_{i n}-v_{i m}\right)}\right) e^{\varepsilon_{i n}} e^{-e^{\varepsilon_{i n}}} d \varepsilon_{i n}
$$

An algebraic solution of this function therefore provides the logistics choice equation

$$
p_{\text {in }}=\frac{e^{v_{\text {in }}}}{\sum_{j} e^{v_{\text {im }}}}
$$

The parameter of the representative utility is specified in linear form such that; ${ }^{v_{i m}}=\beta^{\prime} x_{i m}$

Where $x_{\text {im }}$ is the alternative observed choice $m$.

The final logistics model then becomes

$$
p_{\text {in }}=\frac{e^{\beta^{\prime} x_{i n}}}{\sum_{j} e^{\beta^{\prime} x_{i m}}}
$$

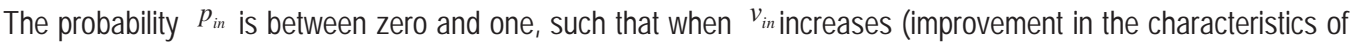
the alternative), if $n \neq m$ is constant then $p_{\text {in }}$ approaches one and if $v_{i n}$ decreases then $p_{i n}$ approaches zero. Equation (16) is the basic logistics equation; therefore any number of choice alternatives can be approximated by it.

This study uses the logit model because tenure choices are unordered, discrete choices. The need to evaluate multiple integrals of the normal distribution renders the probit model weak in this case (Green, 2007). McFadden (1974) indicated that equation (16) could be extended to accommodate other variables such that:

$$
\operatorname{Pr} o b\left(Y_{i}=j / w_{i}\right)=\frac{\exp \left(w_{i}^{\prime} a_{j}\right)}{\sum_{j=1}^{j} \exp \left(w_{i} a_{j}\right)}, j=0,1,2,3 \ldots \ldots
$$

Equation (17) is a multinomial logit model. Its estimation provides a set of probabilities for the $j+1$ choices given $w_{i}$ as the characteristics of the decision maker. Before the model is estimated, it must be made determinable. If 
$a_{j}^{*}=a_{j}+q$ for any vector $\mathrm{q}$, then re-computing the probabilities as defined in equation (17) using $a_{j}^{*}$ instead of $a j$ produces the identical set of probabilities, because all the terms involving q drop out (Greene, 2008) and thus become

$$
\operatorname{Pr} o b\left(Y_{t}=j / w_{t}\right)=P_{i j}=\frac{\exp \left(w_{i}^{\prime} a_{j}\right)}{1+\sum_{k=1}^{J} \exp \left(w_{i}^{\prime} a_{k}\right)}
$$

If the utility of typical Ghanaian household is stated as:

$$
\begin{aligned}
& \text { Utility }=U\left(H_{S I Z E}, L_{G}, L_{F}, L_{C}, L_{U R B}, H_{S E X}, H H_{A G E}, H H_{U N I},\right. \\
& \left.H H_{G R A}, H_{S E C}, H H_{E L E}, H_{E M P}, H H_{W E D}, H_{V} / R^{\prime} I_{P}\right)
\end{aligned}
$$

This utility function therefore yields the estimated multinomial logit of the form:

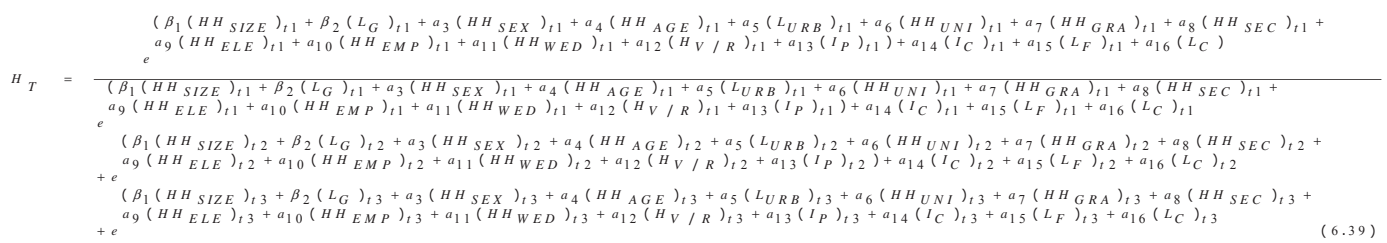

In the estimation, owning was used as the reference alternative with which the remaining housing alternatives (renting and rent free) were compared. Descriptions of the variables are provided in Table 1. The variables prefixed with ' $\mathrm{HH}$ ' denote variables that describe the head of the household. The variables prefixed with ' $\mathrm{H}$ ' denote those that describe

\begin{tabular}{|c|c|}
\hline Variable & Description \\
\hline $\mathrm{H}_{\mathrm{T}}$ & A dummy 1 if the household is owner occupier, 2 if the household is renting and 3 if the household is staying rent free. \\
\hline Ic & Current income of the household \\
\hline $\mathrm{IP}_{\mathrm{P}}$ & Permanent income of the household \\
\hline $\mathrm{I}_{\mathrm{T}}$ & Transitory income of the household \\
\hline $\mathrm{H}_{\text {INDEX }}$ & Estimated price index of housing \\
\hline HHWED & A dummy 1 if the household head is married and 0 otherwise \\
\hline $\mathrm{HH}_{\mathrm{SIZE}}$ & The total number of people in the household \\
\hline $\mathrm{HH}_{\mathrm{SEX}}$ & A dummy 1 if the gender of the household head is male and 0 otherwise \\
\hline $\mathrm{HH}_{\mathrm{EMP}}$ & A dummy 1 if the household head is employed and 0 otherwise \\
\hline $\mathrm{HH}_{\mathrm{ELE}}$ & A dummy 1 if the highest education of the household head is elementary school and 0 otherwise \\
\hline $\mathrm{HH}_{\mathrm{GRA}}$ & A dummy 1 if the highest education of the household head is a post graduate (master's and doctorate) and 0 otherwise \\
\hline $\mathrm{HH}_{\mathrm{SEC}}$ & A dummy 1 if the highest education of the household head is a secondary education and 0 otherwise \\
\hline $\mathrm{HH}_{\text {UNI }}$ & A dummy 1 if the highest education of the household head is university degree and zero otherwise (Honours) \\
\hline $\mathrm{H}_{V / R}$ & Value to rent ratio \\
\hline LURB & Household stays in the urban localities \\
\hline
\end{tabular}
the housing unit and those prefixed with 'L' describe locational variables.

Table 1: Description of Housing Tenure Choice Variables

Source: Author

\section{Results}

\subsection{Descriptive Statistics}

The descriptive statistics (see Appendix A, Tables A1-A3) show that the average rental household has higher average incomes than owner occupied household and rental household spends twice the amount spent by owner occupiers on housing expenditure. The average income of rental household was US\$1400 while for owner occupiers it was US $\$ 1300$ (Appendix A, Table A2). The average income of rent free was also US\$1100. Owner occupiers were older in age than 
renter household heads given the average age of 50 for owner occupiers and 40 for a renter household. The age of household occupying rent free was also 42. Owner occupiers had bigger household size, slept in more rooms and stayed in the rural localities than rental households.

The estimation technique involved three steps. The first step involves the estimation of the permanent income of the households; the second step involves the estimation of the hedonic prices of owner occupiers and that of renters from which price indexes were constructed for both renters and owners (since rent-free do not pay for their use of the housing units they occupy). These indexes were used to construct relative price of ownership to renting and value to rent ratio. The determinants of the tenure equation were then estimated with emphasis on rent free tenure. The estimation of the determinants of tenure choice also involved the following estimation procedure. The first procedure was the estimation of the multinomial logit model. Then, the test for IAA was conducted but the acceptance of the null hypothesis of the IAA assumption ended the estimations. Since this showed that the multinomial logit model was an efficient and consistent estimator for the determinants of the tenure ${ }^{1}$.

\subsection{Factors That Determine the Decision to Rent Relative to Owning}

A household's decision to rent is also influenced by demographic, location, and economic and other factors. Subsection one examines the demographic factors, while subsection two discusses the locational factors and subsection three looks at economic and other factors. Table 2 is the reference for discussion for this section.

\subsubsection{Demographic Characteristics}

A household head with a postgraduate degree has less likelihood of renting relative to a household head without a postgraduate degree, with similar characteristics. If observed at the minimum or maximum characteristics a household head with a postgraduate degree in a rural area has a 16 percent less likelihood of renting relative to a similar household head in a rural locality. With average characteristics a household head with an elementary education has a 2.3 percent greater possibility of renting relative to a household head without a basic qualification but similar characteristics. The gender of the head of the household also determines the decision to rent relative to owning. Male-headed households have a 5 percent less likelihood of renting than female-headed households with average similar characteristics. Older household heads are less likely to rent.

\subsubsection{Locational Characteristics}

The estimated marginal effects from the multinomial logit regression show that only the GAMA ecological zone is not a significant determinant of the decision to rent. Location in the forest ecological zone influences the decision to rent. A household located in this zone has a 5.7 percent greater likelihood of renting relative owning compared to a similar house located elsewhere if the household is evaluated with average characteristics. However, if the household is evaluated with the minimum characteristics, the likelihood of renting reduces to 4.3 percent. In the coastal ecological zone, the likelihood of renting is 5.8 percent greater for households with average characteristics and 5.1 percent greater for households with the minimum or maximum characteristics. Urban households have a 26 percent greater likelihood of renting relative to owning compared to rural household if observed at the average, all other things remaining the same. Observed at the minimum or maximum characteristics, an urban household is 23 percent more likely to rent than a similar household in a rural area.

\subsubsection{Economic and Other Characteristics}

The owner rental ratio is a negative and insignificant determinant of the decision to rent. Increasing permanent income increases the likelihood of renting by 17 percent for a household with the average characteristics and 16 percent for one with minimum or maximum characteristics. Current income also has a positive relationship with the decision to rent, but the magnitude is far less than the influence of permanent income (Table 2). The size of a household also significantly determines the decision to rent. Larger households are less likely to rent, all things being equal, than a smaller household. This is consistent with the literature (Borsch-Supan et al. 2001) that observes that large households need

\footnotetext{
1 The estimates for the permanent income and the price indices are available upon request.
} 
bigger dwellings; renting is not a good choice. Employed household heads have a 3.5 percent less probability of renting relative to unemployed household heads evaluated at the mean characteristics.

Table 2: Determinants of Renting Decision relative to owning

\begin{tabular}{|c|c|c|}
\hline Variable & Marginal Effect (mean) & Marginal Effect (max/min) \\
\hline $\mathrm{HH}_{\text {IIZE }}$ & $-.011451^{\star \star \star}$ & $-.0081397^{\star \star \star}$ \\
\hline$L_{G}$ & .0398264 & .0391219 \\
\hline $\mathrm{L}_{\mathrm{F}}$ & $.0578941^{\star \star}$ & $.0433776^{\star \star}$ \\
\hline Lc & $.0583739^{* \star}$ & $.0511347 * *$ \\
\hline $\mathrm{HH}_{\mathrm{SEX}}$ & $-.0504665^{\star \star}$ & $-.0452985^{\star \star}$ \\
\hline $\mathrm{HH}_{\mathrm{AGE}}$ & 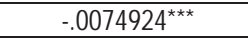 & $-.0064215^{\star \star \star}$ \\
\hline LURB & $2647189^{\star \star \star}$ & $2309637^{\star \star \star}$ \\
\hline $\mathrm{HH}_{\mathrm{SEC}}$ & -.001358 & -.0020184 \\
\hline $\mathrm{HH}_{\text {GRA }}$ & $-.1875652^{\star \star}$ & $-.1689369^{\star \star}$ \\
\hline $\mathrm{HH}_{\mathrm{ELE}}$ & $.0234^{\star}$ & $.0201329^{*}$ \\
\hline HHUNI & -.0282811 & -.0316355 \\
\hline HHEMP & $-.0358129 \star \star$ & $-.0357281^{\star \star}$ \\
\hline $\mathrm{H}_{\mathrm{V} / \mathrm{R}}$ & $\begin{array}{l}-.645966 \\
\end{array}$ & $\begin{array}{l}-.782634 \\
\end{array}$ \\
\hline Ip & $.1726078^{\star \star \star}$ & $.1634525^{\star \star \star}$ \\
\hline$I_{c}$ & $.0132888^{\star \star \star}$ & $.0131271^{\star \star \star}$ \\
\hline
\end{tabular}

Source: Author

\subsection{Factors That Determine the Decision to Stay Rent Free Relative to Owning}

The determinants of rent free relative to owning is presented in this section. Subsections one and two present the estimates and explanation of the demographic and location factors, respectively. Subsection three analyses the economic and other factors. All discussion under this section refers to Table 3.

\subsubsection{Demographic Characteristics}

Age has a negative effect on the decision to stay rent free. Younger households might initially stay rent free until they have the means to afford other modes of tenure. Household heads with a university degree have a 9.4 percent greater likelihood of staying rent free relative to owning, to similar household heads without a degree observed with the mean characteristics. On the other hand, if observed at the minimum or maximum characteristics, a household head with a university degree has an 8.2 percent greater likelihood of choosing rent free housing over owning to a household head with similar characteristics, except for a university degree. This can be explained from two perspectives; graduates mainly find jobs in the urban areas where property prices are high; therefore, they stay with relatives or stay in a rent free family housing unit if they have access to one. Another explanation is that, many graduates' desire to pursue further studies due to the difficulty in finding a job after graduation. The general shortage of accommodation on the various university campuses, especially for postgraduate students forces most of these students to seek out of campus accommodation. Expensive properties and rent, coupled with the exorbitant two or more years advance payment cause these students to seek rent free. Other educational variables are not statistically significant determinants of the decision to stay rent free. The gender of the household head is also not a significant determinant of this decision.

\subsubsection{Locational Factors}

Two locational variables are significant determinants of the decision of a household to choose rent free tenure. Households in the forest zone and in urban localities have a greater likelihood of staying rent free, while the GAMA and coastal ecological zones are not significant determinants of the decision to stay rent free. A household staying in the forest ecological zone has a 12 percent greater likelihood of staying rent free relative to a similar household in other ecological zones in Ghana. Urban households with average characteristics have a 3.6 percent greater likelihood of choosing rent free housing relative to similar households with average characteristics located in rural areas. This might be due to the price of housing and the lack of access to self built housing in the urban areas relative to the rural areas. 
Households choose rent free tenure until they are able to raise money to rent or own.

\subsubsection{Economic and Other Characteristics}

Permanent income and current income are both negatively related to rent free housing tenure choice. An increase in permanent and current income reduces the likelihood of staying rent free by 12.6 and 1.6 percent, respectively of households with average characteristics. The own rent ratio also increases the likelihood of staying rent free but is statistically insignificant. Employed household heads have a 5.1 and 4.8 percent greater likelihood of staying rent free relative to their unemployed counterparts if observed at the average and the minimum or maximum characteristics of the households (Table 3). This can be explained by the fact that some employers provide housing units for their employees, which the GLSS-5 survey classified as rent free. Again, some government employees are also provided with housing which the GLSS-5 also classified as rent free.

Table 3: Determinants of Rent Free Decision Relative to Owning

\begin{tabular}{|c|c|c|}
\hline Variable & Marginal Effect (mean) & Marginal Effect (Min/max) \\
\hline HHSIZE & $-.0291606^{\star \star \star}$ & $-.022709^{\star \star \star}$ \\
\hline$L_{G}$ & -.0453708 & -.0419023 \\
\hline $\mathrm{L}_{\mathrm{F}}$ & $.1260774^{\star \star \star}$ & $.097414^{\star \star \star}$ \\
\hline$L_{c}$ & .0211936 & .0099456 \\
\hline HHSEX & .004413 & .010693 \\
\hline $\mathrm{HH}_{\mathrm{AGE}}$ & $-.0039797 * \star \star$ & $-.0023285^{\star \star \star}$ \\
\hline LURB & $.0848434^{\star \star \star}$ & $.0369935^{* \star}$ \\
\hline $\mathrm{HH}_{\mathrm{SEC}}$ & .0165485 & 0146994 \\
\hline $\mathrm{HH}_{\mathrm{GRA}}$ & -.0104364 & 0147086 \\
\hline HHELE & .0126631 & .0075535 \\
\hline HHuNI & $.0942761^{\star \star}$ & $.0822034^{\star \star}$ \\
\hline $\mathrm{HH}_{\mathrm{EMP}}$ & $.051703^{\star \star}$ & $.0481878^{\star \star \star}$ \\
\hline $\mathrm{H}_{\mathrm{VIR}}$ & 3.14639 & 2.734826 \\
\hline $\mathrm{IP}_{\mathrm{p}}$ & $-.1264296^{\star \star \star}$ & $-.1275013^{* \star \star}$ \\
\hline Ic & $-.0168483^{\star \star \star}$ & $-.0154148^{\star \star \star}$ \\
\hline
\end{tabular}

Source: Author

\subsection{Model Diagnostics Tests}

The strength of a multinomial logit model depends on its ability to pass some basic diagnostics tests (Freese and Long, 2000). Three major tests are performed to determine the suitability and strength of the estimates from the multinomial logit model and to check whether the model is sufficient in explaining the relationships observed or if there is a need to discard it. The section is divided into three parts. The first part tests for the Independence of Irrelevant Alternatives (IAA) assumption. The second presents a Wald test for independence of the variables and the final part presents the Wald test for combining alternatives.

\subsubsection{Test for Independence of Irrelevant Alternatives (IAA) Assumption}

Multinomial logit models are specified on the assumption that the choice sets are independent of the other available alternatives in the model (Greene, 2008: 847). Although this restriction is convenient for estimation it is not good for analysis of a consumer preference (Greene, 2008:847). This restriction has been explained in Microeconometrics circles as the red bus, blue bus problem (Cameron and Trivedi, 2005:503). The red bus, blue bus phenomenon presents a weakness to the multinomial logit estimates. This weakness is tested in this study by using the Small-Hsiao test for IAA. Failure to accept the $\mathrm{H}_{0}$ means that an alternative to the multinomial logit model is needed to re-estimate with the choice of the households housing tenure (Greene, 2008:847)

The result of the test for IAA is shown in Table 4. The test result shows that the $\mathrm{H}_{0}$ of the IAA assumption is accepted. This means that a household's decision to rent relative to owning is independent of the availability of rent free tenure and the decision to stay rent free relative to owning is independent of the availability of rental tenure. The results 
therefore mean that the multinomial logit estimates are appropriate models for estimating the determinants of the choice of tenure in Ghana from a 'trichotomous' choice set.

Table 4: Small-Hsiao Tests for Independent of Irrelevant Alternatives (IIA)

\begin{tabular}{|c|c|c|c|c|c|c|}
\hline omitted & $\operatorname{lnL}($ full) & $\operatorname{lnL}($ omit) & Chi $^{2}$ & df & P>chi & Evidence \\
\hline 2 & -1121.013 & -1112.156 & 17.713 & 14 & 0.220 & For Ho \\
\hline 3 & -743.935 & -737.269 & 13.333 & 14 & 0.500 & For Ho \\
\hline
\end{tabular}

Ho: Odds (Outcome-J vs. Outcome-K) are independent of other alternatives.

\subsubsection{Wald Test for Independence of the Variables}

To examine the independence of all the coefficients associated with a given variable, the study utilized the Wald test for independence. The test results (Table 5) show that GAMA location, and secondary and undergraduate education, are not significant determinants of tenure; the coefficient of each of these variables is zero and they are therefore not determinants of tenure estimation in Ghana. Each of the other variables, except basic education, was found statistically significant at the 5 percent level of significance. Basic education was only significant at 10 percent.

Table 5: Test for Significance of Variables across Estimates

\begin{tabular}{|c|c|c|c|}
\hline Variable & $x^{2}$ & Degree of Freedom & $P>X^{2}$ \\
\hline $\mathrm{HH}_{\text {SIZE }}$ & 131.532 & 2 & 0.000 \\
\hline$L_{G}$ & 2.261 & 2 & 0.323 \\
\hline$L_{F}$ & 50.252 & 2 & 0.000 \\
\hline $\mathrm{Lc}_{\mathrm{C}}$ & 8.642 & 2 & 0.013 \\
\hline $\mathrm{HH}_{\mathrm{SEX}}$ & 6.197 & 2 & 0.045 \\
\hline $\mathrm{HH}_{\mathrm{AGE}}$ & 411.116 & 2 & 0.000 \\
\hline LURB & 294.002 & 2 & 0.000 \\
\hline $\mathrm{HH}_{\mathrm{SEC}}$ & 0.375 & 2 & 0.829 \\
\hline $\mathrm{HH}_{\text {GRA }}$ & 7.241 & 2 & 0.027 \\
\hline $\mathrm{HH}_{\mathrm{ELE}}$ & 5.438 & 2 & 0.066 \\
\hline $\mathrm{HH}_{\text {UNI }}$ & 4.379 & 2 & 0.112 \\
\hline $\mathrm{HH}_{\mathrm{EMP}}$ & 8.882 & 2 & 0.012 \\
\hline $\mathrm{H}_{V / R}$ & 21.830 & 2 & 0.000 \\
\hline$I_{C}$ & 24.093 & 2 & 0.000 \\
\hline$I_{P}$ & 9.478 & 2 & 0.009 \\
\hline
\end{tabular}

Source: Author

\subsubsection{Wald Test for Combining Alternatives}

To prove that each of the housing tenure modes is independent and should not be combined with one another, the Wald test for combining the outcomes was conducted for the three modes of tenure observed in Ghana. The test result (Table 6) shows that each mode of tenure is unique and that none should be combined and two modes of tenure should not be collapsed. This implies that the choice sets are properly categorized in this study.

Table 6: Wald tests for combining alternatives

Source: Author

\begin{tabular}{|l|c|c|c|}
\hline \multicolumn{1}{|c|}{ Alternatives Tested } & $X^{2}$ & Degree of Freedom & $P>X^{2}$ \\
\hline Renting and rent free & 410.415 & 15 & 0.000 \\
\hline Renting and owning & 1013.217 & 15 & 0.000 \\
\hline Rent free and owning & 633.012 & 15 & 0.000 \\
\hline
\end{tabular}




\section{Conclusion}

This chapter examined the determinants of housing tenure in Ghana based on the three major tenure choices in the country. Demographic, locational, and economic and other factors were found to be the main determinants of housing tenure decisions. The rental decisions of households are positively influenced by location in the forest and coastal ecological zone, and an urban location, a head of household with elementary education and the income of the household head. The size of the household, a male-headed household, a household head with postgraduate education and employed household heads have less possibility of renting relative to other modes of tenure. Location in the forest ecological zone, urban location, household heads with bachelor degrees and employed household heads are the main positive determinants of the decision to stay rent free. On the other hand, the size of the household, age of the household head, household heads with postgraduate education, and permanent and current income are negative determinants of the decision to stay rent free.

\section{References}

Arnott, R. 1987. Economic theory and housing. In: MILLS, E.S. ed. Handbook of regional urban economics. Vol. 2 Urban Economics, Amsterdam, Elsevier: 959-988.

Arimah, B. (1997) the Determinants of Housing Tenure Choice in Ibadan, Nigeria. Urban Studies, 34, 105-124.

Borsch-Supan, A. Heiss, F. and Seko, M. 2001. Housing demand in Germany and Japan. Journal of Housing Economics, 10, pp. 229252.

Cameron, A. C. \& Trivedi, P. K. (2005) Microeconometrics, Methods and Application, Cambridge, United Kingdom.

Clark, W. A. V. and Dieleman, F. M. 1996. Households and housing: Choice and Outcomes in the housing Market. Center for Urban Policy Research, Rutgers, New Brunswick.

Daniere, A. (1992) "Determinants of Tenure Choice in the Third World: An Empirical Study of Cairo and Manila", Journal of Housing Economics, 2, pp. 159-184.

Dipasquale, D \& E.L., Glaeser, E.L. (1999) Incentives and social capital: Are homeowners' better citizens? Journal of Urban Economics. 45, pp. 354-384.

Edwards, M. (1990) Rental Housing and the Urban Poor: Africa and Latin America Compared, In Maria Da Piedade Morais and Bruno De Oliveira Cruz (2007) Housing Demand, Tenure Choice and Housing Policy in Brazil. Latin American Real Estate Society.

Engelhardt G. V., Eriksen, M.D., Gale W.G., \& Mills G.B. (2010) What are the social benefits of homeownership? Experimental evidence for low-income households Journal of Urban Economics, 67, pp. 249-258.

Ermisch J., \& Pavalin D. J. (2004) Early childbearing and housing choices Journal of Housing Economics, 13, pp. $170-194$.

Ghana Statistical Services (2005). Population data analysis reports Volume 1\&2, Accra, Ghana

Ghana Statistical Service (2008) Ghana Living Standards Survey Report of the Fifth Round (GLSS 5).

Goodman, A.C. (1988) "An Econometric Model of Housing Price, Permanent Income, Tenure Choice and Housing Demand", Journal of Urban Economics, 23, pp. 327-353.

Goodman, A. C., \& Kawai, M. (1981) Permanent income, hedonic prices, and the demand for housing: New evidence, Journal of Urban Economics 12: pp. 214-237.

Goodman, A. C. 2003. Following a panel of stayers: length of stay, tenure choice, and housing demand. Journal of Housing Economics, 12, pp. 106-133

Greene, W.H. (2008) Econometric Analysis 6th Edition, Prentice Hall, New York, pp. 841-854

Haurin, D. R., Parcel, T. L , and Haurin J. (2002) Does home Ownership affect child outcomes? Real Estate Economics, 30, pp. 635-66 Henderson, J. V., \& loannides, Y .M. (1983) A Model of Tenure Choice, American Economic Review, 73, pp. 78-113.

Ioannides, Y.M., \& Zabel, J. E. (2003) Neighbourhood Effects and Housing Demand, Journal of Applied Econometrics, 18, pp. 563-584. Jones, L. D. 1995. Testing the central prediction of housing tenure transition models. Journal of Urban Economics 38, pp. 50-73

Koizumi, N., \& McCann, P. (2006) Living on a plot of land as a tenure choice: The case of Panama, Journal of Housing Economics, 15, pp. 349-371.

McFadden, D. 1974. The measurement of urban travel demand, Journal of Public Economics, 3, pp. 303-328

Morais, M. D. P. and Cruz, B. D. O. 2007. Housing demand, tenure choice and housing policy in Brazil. Latin American Real Estate Society.

O' Sullivan, A. and Gibb, K. (eds) 2003: Housing Economics and Public Policy. Oxford: Blackwell Publishing

Raya, J., \& Garcia, J. (2012) Which Are the Real Determinants of Tenure? A Comparative Analysis of Different Models of the Tenure Choice of a House, Urban Studies: pp. 1-28.

Rosen, H.S. (1979) Housing Decisions and the U.S. Income Tax: An Econometric Analysis. Journal of Public Economics, 11, pp. 1-23.

Quercia,R. G., McCarthy G. W., \& Wachter S. M. (2003) The impacts of affordable lending efforts on homeownership rates Journal of Housing Economics, 12, pp. 29-59.

Van Lindert, P., \& Westen, (1991) A Household Shelter Strategies in Comparative Perspective: Evidence from Low-Income Groups in Bamako and La Paz, World Development, 19, pp. 1107-1028. 


\section{Appendixes}

Table A1: Descriptive statistics of owner occupier household

Source: Author

\begin{tabular}{|c|c|c|c|c|}
\hline Variable & mean & $\max$ & $\min$ & Std dev \\
\hline $\mathrm{H}_{\mathrm{SEC}}$ & .0717724 & 1 & 0 & .2581672 \\
\hline $\mathrm{H}_{\mathrm{GRA}}$ & .0083151 & 1 & 0 & .0908271 \\
\hline $\mathrm{H}_{\text {ELE }}$ & .4297593 & 1 & 0 & .49515 \\
\hline $\mathrm{H}_{\text {UNI }}$ & .0227571 & 1 & 0 & .1491609 \\
\hline $\mathrm{H}_{\text {WED }}$ & .5513906 & 1 & 0 & .4974121 \\
\hline $\mathrm{H}_{\text {AGE }}$ & 50.32938 & 99 & 17 & 15.79087 \\
\hline $\mathrm{H}_{\mathrm{SEX}}$ & .7639661 & 1 & 0 & .4246946 \\
\hline $\mathrm{H}_{\text {SIZE }}$ & 5.046191 & 29 & 1 & 3.104306 \\
\hline $\mathrm{H}_{\text {EXP }}$ & 355620.5 & 2600000 & 54690.7 & 336605.4 \\
\hline $\mathrm{L}_{\mathrm{RU}}$ & .2309553 & 1 & 0 & .4214948 \\
\hline $\mathrm{H}_{\text {ROOM }}$ & 2.398549 & 12 & 1 & 1.482293 \\
\hline $\mathrm{I}_{\mathrm{C}}$ & $1.23 \mathrm{e}+07$ & $5.30 \mathrm{e}+08$ & $-2.90 \mathrm{e}+07$ & $2.39 \mathrm{e}+07$ \\
\hline $\mathrm{HH}_{\text {EMP }}$ & .8583212 & 1 & 0 & \\
\hline
\end{tabular}

Table A2: Descriptive statistics of rental households

Source: Author

\begin{tabular}{|c|c|c|c|c|}
\hline variable & mean & $\max$ & $\min$ & Std. dev \\
\hline$H_{\text {SEEC }}$ & .0946866 & 1 & 0 & .2928814 \\
\hline$H_{\text {GRA }}$ & .0061308 & 1 & 0 & .0780856 \\
\hline$H_{\text {ELE }}$ & .4843324 & 1 & 0 & .4999248 \\
\hline HHUNI $_{\text {U }}$ & .0415531 & 1 & 0 & .1996337 \\
\hline$H_{\text {AGE }}$ & 39.59378 & 99 & 15 & 12.18032 \\
\hline$H_{\text {SEX }}$ & .7214206 & 1 & 0 & .4484245 \\
\hline$H_{\text {EMP }}$ & .8519755 & 1 & 0 & .112384 \\
\hline$H_{\text {WED }}$ & .628653 & 1 & 0 & .3345122 \\
\hline$H_{\text {SIZE }}$ & 3.430633 & 15 & 1 & 2.209694 \\
\hline$H_{\text {EXP }}$ & 781961.3 & $1.10 \mathrm{e}+07$ & 5400 & 1006669 \\
\hline LUR & .7946726 & 1 & 0 & .4040528 \\
\hline$H_{\text {ROOM }}$ & 1.436182 & 7 & 1 & .7595993 \\
\hline $\mathrm{I}_{\mathrm{C}}$ & $1.31 \mathrm{e}+07$ & $2.40 \mathrm{e}+08$ & $-4.50 \mathrm{e}+07$ & $1.78 \mathrm{e}+07$ \\
\hline
\end{tabular}

Table A3:Descriptive statistics of rent free households

Source: Author

\begin{tabular}{|c|c|c|c|c|}
\hline Variable & mean & max & min & Std. dev \\
\hline $\mathrm{H}_{\text {SEC }}$ & .0776231 & 1 & 0 & .2676493 \\
\hline $\mathrm{H}_{\text {GRA }}$ & .0042827 & 1 & 0 & .0653192 \\
\hline $\mathrm{H}_{\text {ELE }}$ & .4694861 & 1 & 0 & .4992017 \\
\hline $\mathrm{H}_{\text {UNI }}$ & .0299786 & 1 & 0 & .1705739 \\
\hline $\mathrm{H}_{\text {WED }}$ & .532341 & 1 & 0 & 0.451189 \\
\hline $\mathrm{H}_{\text {AGE }}$ & 41.83923 & 96 & 15 & 15.02453 \\
\hline $\mathrm{H}_{\text {SEX }}$ & .6576107 & 1 & 0 & .4745974 \\
\hline $\mathrm{H}_{\text {SIZE }}$ & 3.478229 & 18 & 1 & 2.361934 \\
\hline $\mathrm{H}_{\text {EXP }}$ & 392475.5 & 2600000 & 74863.6 & 334695.2 \\
\hline $\mathrm{L}_{\text {UR }}$ & .4387793 & 1 & 0 & .4963302 \\
\hline $\mathrm{H}_{\text {ROOM }}$ & 1.461481 & 8 & 1 & .8493709 \\
\hline $\mathrm{I}_{\mathrm{C}}$ & $1.06 \mathrm{e}+07$ & $4.90 \mathrm{e}+08$ & $-1.10 \mathrm{e}+08$ & $1.98 \mathrm{e}+07$ \\
\hline
\end{tabular}

